\title{
PEMBUATAN POLA BUSANA SECARA OTOMATIS MENGGUNAKAN GARIS DAN KURVA B-SPLINE
}

\author{
Muwardi Raharjo ${ }^{1)}$, Isye Arieshanti ${ }^{2)}$, Nanik Suciati ${ }^{3)}$ \\ ${ }^{1,2,3)}$ Jurusan Teknik Informatika \\ Institut Teknologi Sepuluh Nopember \\ Surabaya, Indonesia \\ email: $\underline{\text { muwardi@cs.its.ac.id }}^{1)}, \underline{\text { i.arieshanti@if.its.ac.id }}{ }^{2)}, \underline{\text { nanik@if.its.ac.id }}^{3)}$
}

\begin{abstract}
Abstrak
Dalam industri pembuatan busana, proses pembuatan pola busana secara manual akan membutuhkan waktu lama dan memerlukan keahlian pembuatan pola, sehingga mempengaruhi waktu dan biaya produksi. Pada industri skala besar, pembuatan pola busana dilakukan secara otomatis menggunakan teknologi modern. Tetapi teknik ini membutuhkan alat canggih yang mahal. Terlebih lagi, pemanfaatan teknik tersebut belum dapat melakukan variasi mengenai detail busana yang akan dibuat seperti variasi jenis kerah, variasi jenis lengan, variasi jenis rok, celana dan sebagainya.

Pada penelitian ini diusulkan sebuah sistem pembuatan pola busana secara otomatis menggunakan garis dan kurva b-spline. Kelebihan dari sistem ini mampu untuk membuat pola busana beserta variasi detailnya. Di samping itu, pemakai juga dapat membuat pola tanpa harus memiliki keahlian dalam pembuatan pola. Secara umum, pembuatan pola busana dibagi menjadi empat tahap, yaitu pemilihan jenis busana, variasi detail desain busana, pengaturan ukuran busana, dan pembuatan pola busana. Hasil prosentase kemiripan pola yang dihasilkan sistem dengan data benarnya sebesar 59\% Sangat Mirip, 28\% Mirip, 11\% Kurang Mirip, dan 2\% Tidak Mirip. Dengan adanya sistem ini, pembuatan pola busana menjadi lebih cepat dengan biaya yang lebih terjangkau jika dibandingkan dengan alat-alat penggambar pola yang sudah ada.
\end{abstract}

Kata kunci : garis, kurva b-spline, pola busana, variasi detail busana.

\begin{abstract}
In the industrial manufacture of clothing, fashion pattern making in manually will take a long time and requires a pattern-making skills, thus affecting the time and cost of production. In the large-scale industry, fashion pattern making is done automatically using modern technology. But this technique requires sophisticated tools and it is expensive. Moreover, this technique have not been able to do variations on the clothing details that will be made, such as variations collar type, sleeve type variations, variations in types of skirts, pants and so on.

This study proposed an automatic fashion pattern making system using lines and b-spline curves. The advantage of this system is able to make a dress pattern and the variation in details. Moreover, users can make a pattern without having expertise in fashion pattern making. Generally, manufacturing of fashion pattern is divided into four stages i.e. the selections of clothing, detail variations fashion design, the setting of fashion size, and fashion pattern making.Results ofsimilaritypatterns between the system and groundtruth i.e 59\% VerySimilar, 28\% Similar, 11\% LessSimilar, and $\%$ NotSimilar. With this system, the process of pattern making fashion more quickly with lower cost when compared with the drawing tools existing pattern.
\end{abstract}

Keywords: b-spline curves, fashion patterns, line, variations fashion detail.

\section{PENDAHULUAN}

Dalam pembuatan busana, tahap awal yang sering dilakukan adalah membuat pola busana.Pola busana diperlukan untuk mempermudah pembuatan busana dan untuk mendapatkan hasil yang lebih baik.Pada umumnya, pembuatan pola busana dilakukan secara manual melalui sketsa di atas kertas. Bagi orang awam, teknik ini tidak mudah karena untuk membuat pola busana secara manual diperlukan keahlian dan pengalaman dalam membuat pola. Selain itu, teknik pembuatan pola ini membutuhkan waktu yang lama sehinggaproses pembuatan busanamenjadi kurang maksimal[1].
Selain dilakukan secara manual, pembuatan pola busana dapat dilakukan dengan cara otomatis menggunakan teknologi CAD (Computer Aided Design). Teknik ini didasarkan pada perhitungan matematika terhadap detail ukuran busana yang akan dibuat. Dengan teknologi ini, proses produksi menjadi lebih cepat sehingga pembuatan busana menjadi lebih maksimal. Tetapi teknologi ini belum memungkinkan membuat variasi jenis busana yang akan dibuat, misalnya membuat variasi jenis kerah, jenis lengan, jenis celana, jenis rok, dan sebagainya.Di samping itu,teknik ini membutuhkan alat canggih dan mahal sehingga kurang cocok digunakan dalam industri skala kecil sampai menengah. 
Pada penelitian ini diusulkan sebuah sistempembuat pola busana secara otomatis dengan harga yang lebih terjangkau. Pengembangan sistem ini menggunakan metode garis dan kurva b-spline untuk membuat desain pola busana. Tidak seperti penelitian sebelumnya [1] yang menggunakan scan tiga dimensi dalam mengukur tubuh pemakai, sistem ini menyediakan ukuran standar seperti S, M, dan L. Selain karena ukuran busana pada umumnya sudah terstandar, penyediaan ukuran ini lebih aplikatif bagi industri garmen skala kecil dan menengah. Selain itu, kelebihan sistem yang diusulkan ini jika dibandingkan dengan penelitian sebelumnya[1] adalah adanya variasi detail model yang disediakan. Untuk mendapatkan sketsa pola busana, dapat dilakukan hanya dengan memilih beberapa jenis busana beserta detail yang telah disediakan sistem. Dengan demikian, pengguna lebih mudah untuk membuat desain pola busana tanpa harus memiliki keahlian dalam pembuatan pola.

\section{TINJAUAN PUSTAKA}

Pada bagian ini, akan dijelaskan mengenai teori-teori yang menjadi landasan dalam melakukan penelitian seperti desain busana, pembuatan grafik, dan model transformasi.

\subsection{Desain Busana}

\subsubsection{Pengertian Busana}

Busana merupakan bahan tekstil atau bahan lainnya yang dipakai untuk menutupi tubuh seseorangsehingga dapat menampilkan keindahan dan memberikan rasa nyaman bagi pemakainya[2].Secara garis besar, busana dibagi menjadi tiga jenisyaitu busana pokok, busana pelengkap, dan busana penambah[3].Busana pokok merupakan jenis pakaian yang dipakai pada tubuh manusia, baik tubuh bagian atas maupun tubuh bagian bawah, misalnyablouse, T-shirt, kemeja, kebaya, rok, dan celana.Busana pelengkap (millineris), yaitu benda yang berfungsi sebagai pelengkap dalam berbusana. Contohnya alas kaki, tas, topi, ikat pinggang, dan sarung tangan.Busana penambah (accesories) merupakan benda yang digunakan sebagai penambah keindahan dalam berbusana, seperti pita rambut, bandana, antinganting, kalung, gelang tangan, kacamata, dan cincin.

Pada busana yang bersifat pokok, terdapat beberapa jenis detail busana seperti jenis lengan, jenis kerah, jenis celana, jenis rok, jenis kulot, dan sebagainya. Sebuah busana dapat menggunakan beberapa variasi detail busana itu sesuai dengan nilai keserasian serta keinginan dari pemakai. Adapun contoh dari variasi detail busana mengenai jenis rok adalah rok standar, rok span, rok lipit hadap satu, rok lipit sungkup, rok lipit pipih, rok kerut, dan sebagainya.

\subsubsection{Pola Busana}

Pola busana merupakan ciplakan bentuk badan yang biasa dibuat di kertas, yang nanti dipakai sebagai contoh untuk menggunting kain dalam pembuatan busana. Pola ini merupakan hal yang sangat penting dalam pembuatan busana, karena baik tidaknya busana yang dihasilkan sangat dipengaruhi oleh kebenaran atau kesesuaian pola busananya. Dengan adanya pola yang sesuai, maka pembuatan busana menjadi lebih mudah dan terarah sehingga hasilnya sesuai dengan yang dikehendaki. Adapun bentuk pola busana berupa pola badan ditunjukkan pada Gambar 1.

Dalam pengukuran pola busana, terdapat dua jenis metode yang digunakan, yaitu metode ukuran pola konstruksi dan metode ukuran pola standar. Pola konstruksi merupakan pola yang dibuat berdasarkan ukuran konstruksi tubuh seseorang yang masing-masing orang mempunyai ukuran tertentu. Teknik ini membutuhkan waktu yang lama karena diperlukan pengukuran secara langsung terhadap ukuran tubuh pengguna. Contoh parameter ukuran tubuh yang diukur dalam pembuatan pola busana ditunjukkan pada Tabel 1 [4]. Sedangkan pola standar merupakan pola yang dibuat

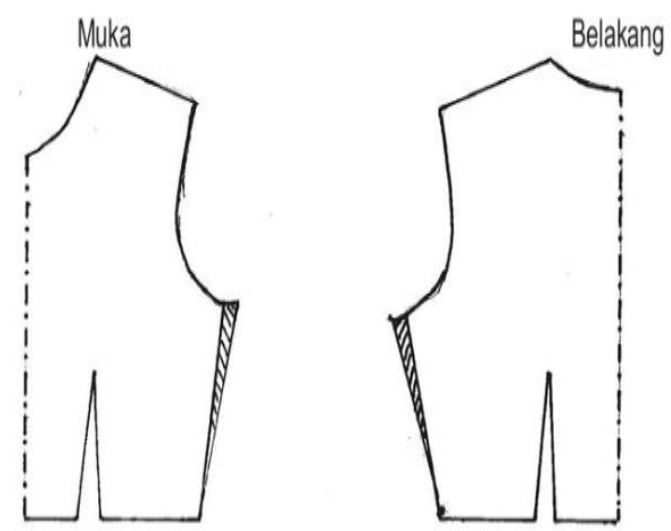

Gambar1Poladasarbusana[2]

Tabel1 Parameter ukuranpolakonstruksi

\begin{tabular}{cl}
\hline Jenis & \multicolumn{1}{c}{$\begin{array}{c}\text { Parameter yang } \\
\text { digunakan }\end{array}$} \\
& \multicolumn{1}{c}{ Panjangkemeja, } \\
& lebarpunggung, \\
Kemeja (Pria) & $\begin{array}{l}\text { lingkarbadan, lingkarleher, } \\
\text { panjanglengan, } \quad 1 / 2\end{array}$ \\
& lingkarlengan, rendahbahu, \\
& rendahpunggung, \\
\hline
\end{tabular}




\begin{tabular}{llr}
\hline \multicolumn{3}{c}{ panjangpunggung } \\
\hline & Lingkarpinggang, \\
Celanapanjang & panjangcelana, \\
(wanita) & lingkarpesak, & $1 / 2$ \\
& lingkarpaha, $1 / 2$ \\
& lingkarlutut, 1/2 lingkar kaki \\
\hline berdasarkandaftarukuranumumataukuran yang
\end{tabular}
telahdistandarkan, sepertiukuranSmall (S), Medium (M), danLarge

Denganteknikiniakanlebihmudahdancepatkarenatida kdiperlukanpengukuransecaralangsungterhadappem akai. Adapunbeberapacontohukuran yang telahdistandarisasiditunjukkanpadaTabel2.[4].

\subsection{Pembuatan Grafik}

Dalam pembuatan sketsa pola busana, diperlukan beberapa komponen pembuatan grafik seperti garis lurus, garis lengkung, dan kurva bspline yang akan dijelaskan pada bagian berikut.

\subsubsection{Garis Lurus}

Garis lurus merupakan bentuk paling sederhana dari sebuah kurva dua dimensi. Garis dibentuk dari dua buah titik dengan koordinat berbeda yang dihubungkan sehingga berbentuk lurus. Garis lurus disebut juga kurva linier yang dirumuskan sebagai berikut.

$$
\boldsymbol{y}=\boldsymbol{m} \boldsymbol{x}+\boldsymbol{c}
$$

dimana $m$ merupakan gradient (kemiringan) garis, $c$ merupakan nilai konstanta yang menunjukkan titik potong kurva tersebut terhadap sumbu Y.

Gradien garis lurus $(m)$ merupakan nilai perbandingan komponen Y (vertikal) dan komponen $\mathrm{X}$ (horizontal) antara dua titik pada garis lurus tersebut. Sebagai contoh, terdapat garis lurus $y=m x+c$, dimana koordinat awalnya adalah $\left(x_{1}, y_{1}\right)$ dan koordinat akhirnya adalah $\left(x_{2}, y_{2}\right)$, maka nilai gradient $(m)$ dapat dirumuskan seperti pada persamaan (2).

$$
m=\frac{y_{2}-y_{1}}{x_{2}-x_{1}}
$$

Tabel2. Parameter ukuranpolastandar

\begin{tabular}{clccc}
\hline \multirow{2}{*}{ Jenis } & \multirow{2}{*}{ Parameter } & \multicolumn{3}{c}{ Ukuran $(\mathbf{c m})$} \\
\cline { 3 - 5 } & & $\mathbf{S}$ & $\mathbf{M}$ & $\mathbf{L}$ \\
\hline \multirow{6}{*}{$\begin{array}{c}\text { Kemjangkemeja } \\
\text { Pria }\end{array}$} & 69 & 71 & 74 \\
& Lebarpunggun & 42 & 44 & 47 \\
& lingkarbadan & 84 & 92 & 100 \\
& lingkarleher & 36 & 38 & 41 \\
& panjanglengan & 55 & 57 & 60 \\
& lingkarlengan & 16 & 17 & 18.5 \\
& panjangpunggu & & & \\
& ng & 38 & 40 & 43 \\
\hline Celana & Panjangcelana & 92 & 96 & 102
\end{tabular}

\begin{tabular}{clllc} 
Panjang & lingkarpinggan & 72 & 76 & 82 \\
Pria & g & & & \\
& $1 / 2$ lingkarpaha & 28 & 30 & 33 \\
& $1 / 2$ lingkarlutut & 22 & 23 & 25 \\
& $1 / 2$ lingkar kaki & 16 & 18 & 21 \\
& panjanglutut & 52 & 54 & 55.5 \\
\hline
\end{tabular}

\subsubsection{Kurva Lengkung}

Kurva lengkung merupakan kurva yang berbentuk lengkung dan bersifat non-linear. Kurva lengkung dapat terbentuk dari fungsikuadrat, kubik, sinus, cosinus, dan sebagainya. Bentuk kurva ini berupa kurva parabola, lingkaran, elips, kurva sinusoidal, dan yang lainnya. Berbeda dengan garis lurus yang hanya mempunyai satu nilai gradien, pada kurva lengkung ini mempunyai banyak nilai gradient. Untuk mencari gradient pada kurva lengkung, dapat dilakukan dengan mencari turunan pertama pada fungsi kurva tersebut. Misalnya pada kurva lengkung $y=a x^{2}+b x+c$, maka nilai gradient $m$ dapat dirumuskan sebagai berikut.

$$
m=\frac{d y}{d x}
$$

Dari contoh sebelumnya, gradien fungsi $y=a x^{2}+b x+c$ pada koordinat $x$ adalahm $=$ $2 a x+b$.

\subsubsection{Kurva B-spline}

Kurva $B$-spline merupakan kurva spline yang menggunakan fungsi basis atau blending function. Dalam fungsi basis ini, suatu kurva direpresentasikan sebagai kombinasi titik kontrol yang dimiliki kurva tersebut. Kurva ini disusun oleh fungsi basis B-spline dengan knot yang berjarak sama. Persamaan umum kurva bspline ditunjukkan pada persamaan (4) [5].

$$
\boldsymbol{f}(\boldsymbol{u})=\sum_{k=0}^{n} P_{k} B_{k, d}(u)
$$

dengan $t_{d-1} \leq u \leq t_{n+1}$ dimana $\boldsymbol{P}_{\boldsymbol{k}}$ merupakan titik kontrol, $n+1$ merupakan jumlah titik kontrol. B-spline $\boldsymbol{B}_{\boldsymbol{k}, \boldsymbol{d}}$ merupakan polinomial berderajat $(d-1)$ dengan $d$ merupakan derajat dari kurva $b$-spline. $t_{d-1}$ merupakan nilai knot.

Persamaan untuk mendefiniskan fungsi basis menggunakan formula Cox-Deboor untuk $d=1$ adalah sebagai berikut.

$$
\boldsymbol{B}_{k, \mathbf{1}}(\boldsymbol{u})=\left\{\begin{array}{lr}
\mathbf{1} & \text { jika }_{\boldsymbol{i}} \leq \boldsymbol{u} \leq \boldsymbol{u}_{\boldsymbol{i}+\mathbf{1}} \\
\mathbf{0} & \text { lainnya }
\end{array}\right.
$$

Sedangkan rumusan untuk $d>1$ ditunjukkan pada persamaan (6) [5]. 


$$
\begin{aligned}
& B_{k, d}(u) \\
& =\frac{u-u_{k}}{u_{k+d-1}-u_{k}} B_{k, d-1}(u) \\
& +\frac{u_{k+d}-u^{\prime}}{u_{k+d}-u_{k+1}} B_{k+1, d}(u)
\end{aligned}
$$

dimana setiap fungsi basis didefinisikan melalui subinterval $d$ pada rentang $u$. Kemudian setiap ujung subinterval $\boldsymbol{u}_{j}$ disebut knot. Pemilihan vektor knot tertentu menyebabkan terjadinya bentuk $0 / 0$, sehingga hasilnya ditetapkan sebagai nilai 0 .

Contoh kurva $b$-spline dengan tiga titik kontrol ditunjukkan pada Gambar 2

\subsection{Model Transformasi}

\subsubsection{Vektor dan Matriks}

Dalam ruang dua dimensi, suatu titik dapat direpresentasikan menjadi vektor terhadap komponen $x$ dan komponen $y$ yang berbentuk vektor kolom. Misalnya vektor $\mathrm{p}$ bernilai $x i+y j$, maka representasinya ditunjukkan pada persamaan (7)[6].

$$
p \leftarrow\left[\begin{array}{l}
x \\
y \\
1
\end{array}\right]
$$

Angka 1 pada vektor $\mathrm{p}$ menunjukkan sebuah homogeneous. Misalnya titik $p$ ditransformasikan terhadap matriks $M$ sehingga menghasilkan titik $p$, maka persamaannya dapat dituliskan sebagai berikut.

$$
\boldsymbol{p}^{\prime}=\boldsymbol{M} \cdot \boldsymbol{p}
$$

\subsubsection{Operasi Matriks}

Suatu vektor dapat ditransformasi terhadap matriks tertentu menggunakan beberapa jenis operasi matriks seperti translasi, dilatasi, dan rotasi. Proses transformasi matriks ini dapat dilakukan beberapa kali terhadap sebuah matriks awal. Misalnya matriks awal $p$ ditransformasi terhadap matrik $M$ kemudian dilanjutkan dengan transformasi terhadap matriks $N$. Hasil transformasi awal terhadap matriks $\mathrm{M}$ adalah $p^{\prime}$ (sesuai dengan persamaan 5).Sedangkan hasil transformasi terhadap matriks $N$ adalah $N . p^{\prime}$. Secara keseluruhan, hasil akhir dari transformas tersebut adalah N.M.p.

Berikut ini akan dijelaskan mengenai operasi matriks secara umum.

\section{a. Translasi}

Translasi digunakan untuk melakukan pergeseran terhadap posisi koordinat $\mathrm{x}$ dan $\mathrm{y}$. Misalnya matriks $v(x, y)$ ditranslasi terhadap matriks $T\left(t_{x}, t_{y}\right)$, maka dapat dirumuskan seperti pada persamaan (9) [7].

$$
v^{\prime}=\left[\begin{array}{ccc}
1 & 0 & t x \\
0 & 1 & t y \\
0 & 0 & 1
\end{array}\right] \cdot\left[\begin{array}{l}
x \\
y \\
1
\end{array}\right]
$$

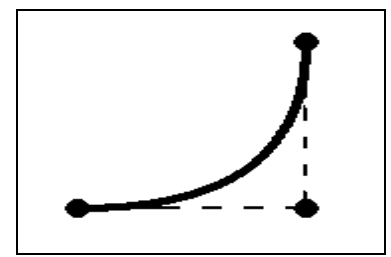

Gambar2.Kurvab-spline

\section{b. Dilatasi / skala}

Proses ini digunakan untuk merubah matriks dengan caramengalikan komponen matriks awal dengan konstanta tertentu. Dalam suatu bidang, operasi ini digunakan memperbesar atau memperkecil ukuran bidang tersebut. Misalnya matriks $v(x, y)$ didilatasi terhadap matriks $S\left(s_{x}, s_{y}\right)$ maka dirumuskan sebagai berikut [7].

$$
v^{\prime}=\left[\begin{array}{ccc}
s x & 0 & 0 \\
0 & s y & 0 \\
0 & 0 & 0
\end{array}\right] \cdot\left[\begin{array}{l}
x \\
y \\
1
\end{array}\right]
$$

\section{c. Rotasi}

Rotasi digunakan untuk mengubah nilai matriks awal dengan cara memutarnya terhadap poros tertentu sebesar beberapa derajat. Rotasi matriks awalT(x,y)sebesar Øderajatdapat dirumuskan seperti pada persamaan (11) [7].

$$
M=\left[\begin{array}{ccc}
\cos \emptyset & -\sin \emptyset & 0 \\
\sin \emptyset & \cos \emptyset & 0 \\
0 & 0 & 0
\end{array}\right] \cdot\left[\begin{array}{l}
x \\
y \\
1
\end{array}\right]
$$

\section{METODE}

Pada bagian ini akan dijelaskan mengenai metode yang digunakan dalam pembuatan sistem.

\subsection{Fungsi Penggambaran Pola Busana}

Dalam proses penggambaran pola busana, dibuat fungsi-fungsi utama sebagai berikut.

a. lines([koordinatawal; koordinatakhir], jenis_garis, operator)

Fungsi ini digunakan untuk menggambar garis lurus dari posisi koordinat awal sampai koordinat akhir.

b. kurva([titik_kontroll; titik_kontrol2;....;itik_kontroln],jenis_ga ris, operator)

Fungsi ini menggambar kurva b-spline dari titik kontrol ke-1 sampai dengan titik kontrol ke n.

c. oval_2([titik_pusat; panjanglebar], jenis_garis, operator,arah) 
Fungsi ini digunakan untuk menggambar kurva lengkung setengah oval dengan panjang, lebar,dan arah tertentu.

d. oval_4([titik_pusat; panjanglebar], jenis_garis, operator,arah)

Fungsi ini digunakan untuk menggambar kurva lengkung seperempat oval dengan panjang, lebar, dan arah tertentu. Adapun jenis garis berupa titik-titik, garis penuh, atau garis potong-potong, sedangkan operator digunakan sebagai keterangan dalam proses transformasi seperti translasi, dilatasi, dan rotasi.

Contoh salah satu penerapanfungsi-fungsi di atas untuk menggambar pola rok lingkaran ditunjukkan pada Gambar 3.

\subsection{Pembuatan Pola Busana}

Pada penelitian ini, terdapat empat tahapan proses yaitu pemilihan jenis busana, pemilihan detail busana, pemilihan ukuran, dan pembuatan pola busana. Tahapan proses ini digambarkan dalam diagram alir pada Gambar 4. Adapun penjelasan detail mengenai keempat

tahapan tersebut adalah sebagai berikut.

1) PemilihanJenisBusana

Terdapat beberapa jenis busana yang telah disediakan dalam sistem ini, diantaranya baju, kemeja, kaos, celana, rok, dan blus. Pengguna dapat memilih jenis busana tersebut sesuai dengan keinginannya.

2) Variasi Detail DesainBusana

Proses ini digunakan untuk menentukan detail desain busana yang akan dibuat seperti penentuan jenis kerah dan jenis lengan untuk busana atas. Adapun untuk busana bawah dapat berupa penentuan jenis rok atau jenis celana yang akan dibuat. Tahapan ini merupakan proses yang belum ada pada sistem-sistem yang telah dikembangkan sebelumnya[1].

3) PengaturanUkuranBusana

Dalam sistem ini, ukuran busana terbagi menjadi dua jenis yaitu berdasarkan ukuran konstruksi tubuh dan ukuran standar baju. Pada jenis ukuran konstruksi tubuh, data masukan berupa angka-angka hasil pengukuran tubuh dari pengguna busana seperti lebar dada, lebar lengan, lebar pundak, panjang punggung, dan sebagainya. Sedangkan pada jenis ukuran standar baju terdapat tiga jenis ukuran yaitu $S$, M, dan L. Dari ketiga jenis tesebut, masingmasing ukuran detailnya telah tersimpan dalam database ukuran standar baju. Oleh karena itu ketika ukuran tersebut dimasukkan, maka secara otomatis detail ukurannya yang tersimpan juga akan disertakan.

4) PembuatanPolaBusana

Dalam membuat pola busana, diperlukan adanya aturan atau langkah-langkah dalam pembuatanpola busana. Aturan-aturan tersebut

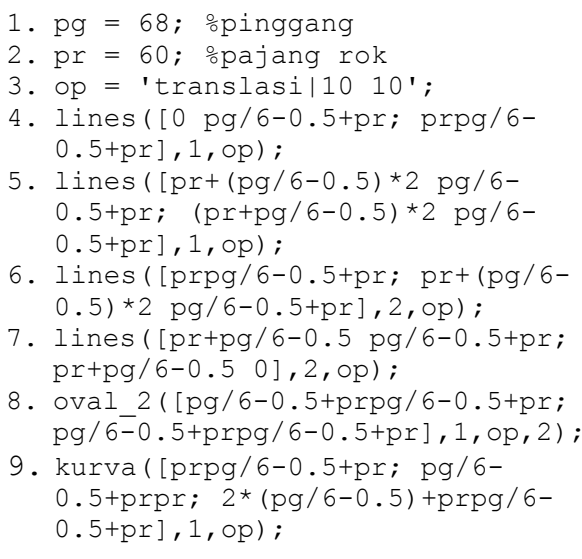

Gambar 3. Penerapan fungsi-fungsi dasar pembuatan pola rok lingkaran 


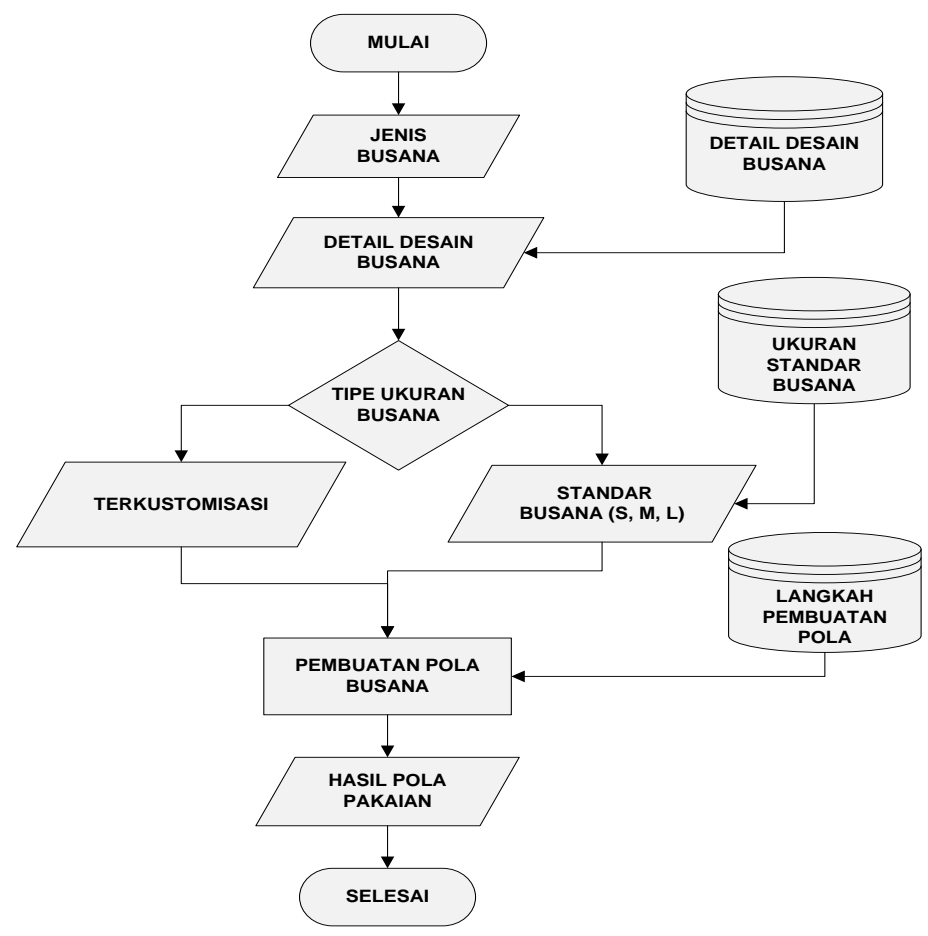

Gambar 4. Diagram alirsistem

telah dibuat ke dalam bentuk fungsi-fungsi pembuat pola busana seperti fungsi pembuat rok, celana, kemeja, dan sebagainya. Masing-masing fungsi ini mempunyai parameter masukan yang berbeda tergantung pada jenis busananya. Dengan fungsifungsi tersebut, maka pola busana dapat dibuat berdasarkan nilai parameter ukuran yang dimasukan.

\section{UJICOBA DAN ANALISIS}

Pada bagian ini akan dijelaskan mengenai proses pengujian sistem, apakah fungsionalitas sistem telah menghasilkan output yang sesuai.

\subsection{Data}

Data yang digunakan dalam sistem ini berupa sketsa pola busana sebanyak 44 pola. Data itu dibagi menjadi dua bagian, data benar dan data uji masingmasing sebanyak 22 data. Data benar diperoleh dari buku-buku atau literatur lain yang disketsa ulang. Sedangkan data yang diuji adalah data gambar pola busana hasil keluaran sistem.

\subsection{Skenario Pengujian}

Secara umum, skenario pengujian yang dilakukan adalah dengan menguji fungsionalitas sistem dan menguji pola busana yang dihasilkan. Pola busana diuji secara kualitatif menggunakan teknik kuesioner. Kuesioner ini diberikan kepada 30 responden untuk menilai kemiripan bentuk pola busana yang dihasilkan sistem dengan data benar pola busana. Adapun skenario pengujian yang digunakan adalah sebagai berikut.

(a) Melakukanpembuatanpolabusana

(b) Melakukanvariasi data masukan

(c) Membandingkanpolabusana yang dihasilkansistemdengan data benar

\subsection{Hasil Ujicoba}

Pada penelitian ini, dihasilkan sebuah antarmuka sistem beserta hasil desain pola busananya yang ditunjukkan pada Gambar 5. Setelah dilakukan proses variasi data masukan (Tabel 3), maka pola busana yang dihasilkan dapat dilihat pada Gambar 6. Sedangkan hasil pengujian menggunakan kuesioner dapat dilihat pada Gambar 7. Secara garis besar, jenis pola busana yang telah berhasil dibuat dari sistem ini ditunjukkan pada Tabel 4.

Pada Gambar 6 (a) merupakan pola kemeja wanita yang terdiri dari tiga bagian yaitu kerah, lengan, dan badan. Sedangkan pada Gambar 6 (b) merupakan pola rok kerut yang terdiri dari tiga bagian yaitu pola depan, pola belakang, dan pola ban pinggang. Pada pola-pola ini, terdapat garis putus-putus bagian luar yang menunjukkan daerah perluasan dari pola. Garis ini digunakan sebagai tempat pemotongan kain sehingga terdapat area untuk tempat jahitan. 
SYSTEMIC

Vol. 1, No. 1, Agustus 2015, 5-13

Tabel 3. Variasi data masukan

\begin{tabular}{cccc}
\hline No & $\begin{array}{c}\text { Jenis } \\
\text { busana }\end{array}$ & Variasi detail & Ukuran \\
\hline \multirow{2}{*}{ a } & Kemeja & $\begin{array}{c}\text { Kerah : tegak, } \\
\text { Lengan : licin }\end{array}$ & $\mathrm{S}$ \\
\hline
\end{tabular}

\begin{tabular}{llll}
\hline $\mathrm{b}$ & Rok & Kerut & $\mathrm{M}$ \\
\hline
\end{tabular}

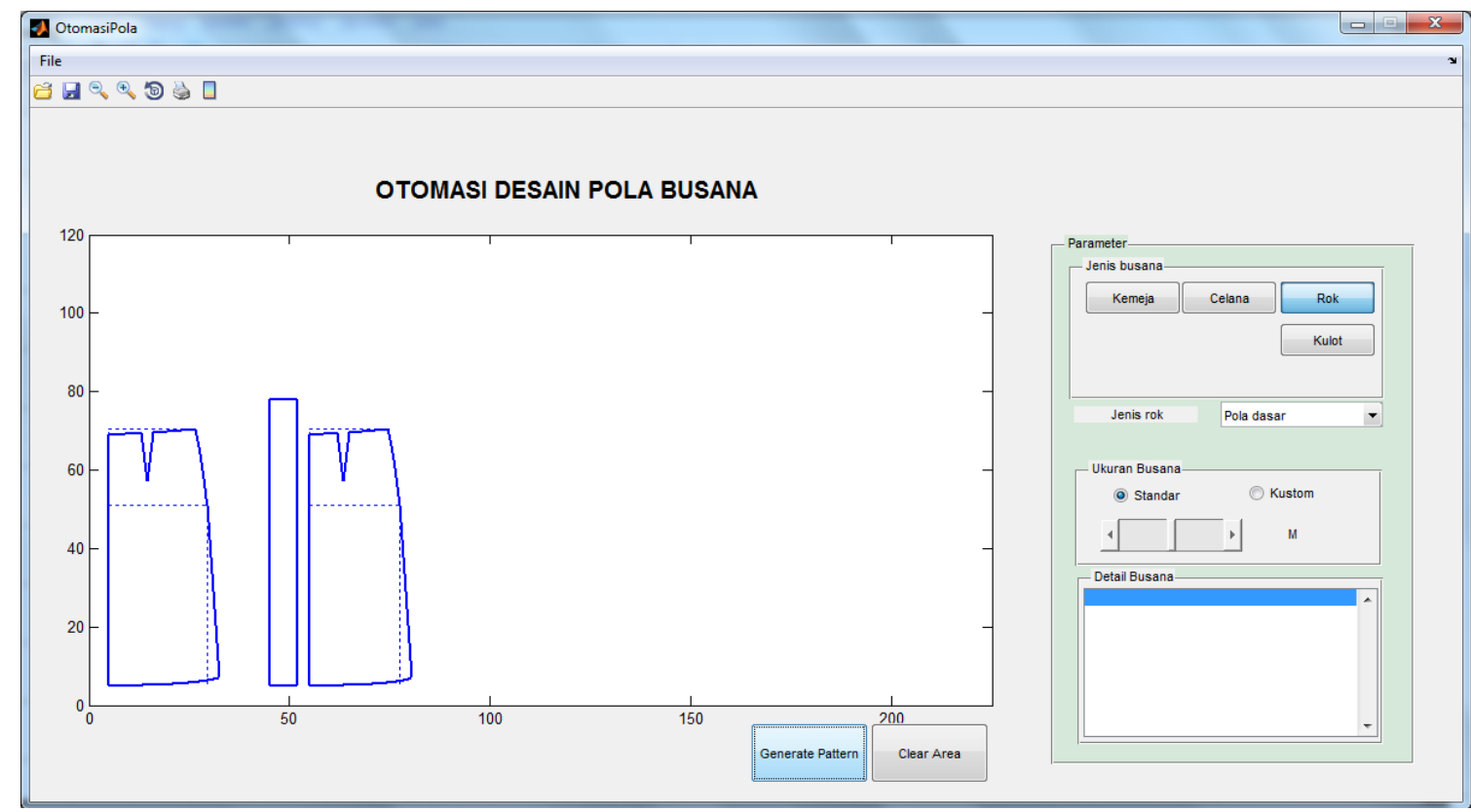

Gambar 5. Interface Sistem

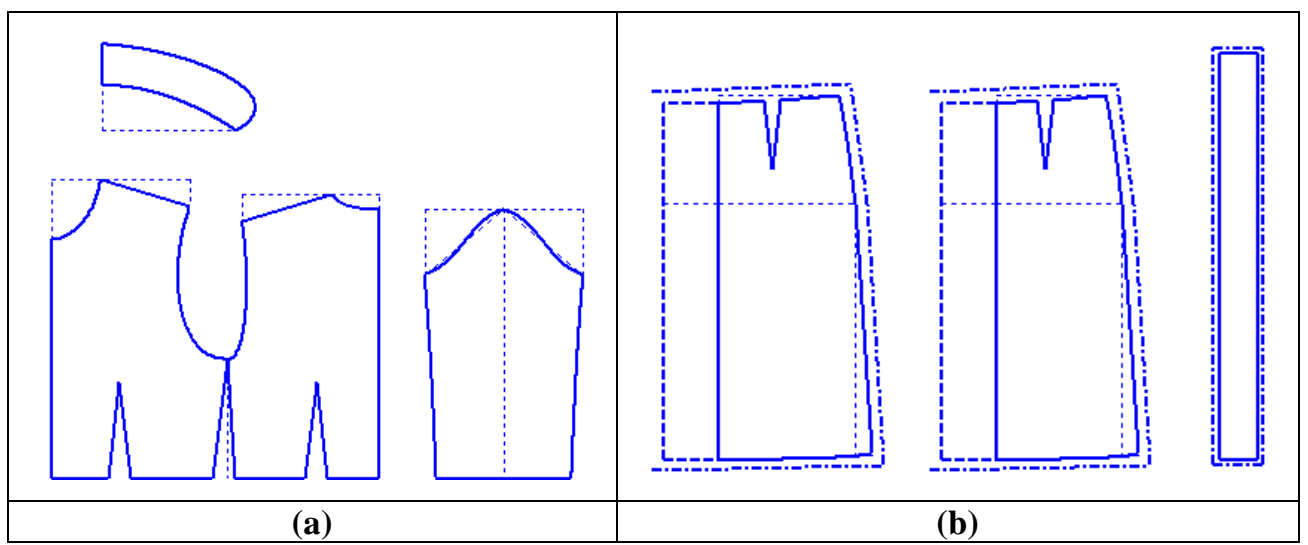

Gambar 6. (a) Pola kemeja, (b) Pola rok kerut 


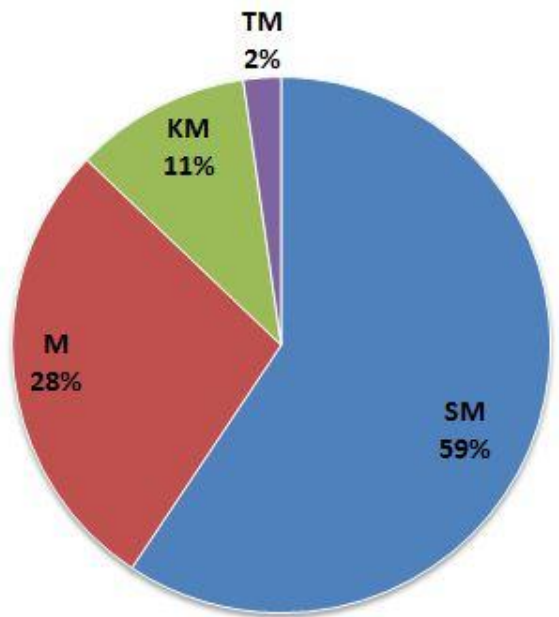

Gambar 7. Hasil pengujian dengan kuesioner

Keterangan :

SM : Sangat Mirip, M : Mirip,

KM : Kurang Mirip, dan TM : Tidak Mirip.

Tabel4. Jenispolabusana yang dihasilkansistem

\begin{tabular}{ccl}
\hline No & Jenis & \multicolumn{1}{c}{ Variasi yang dihasilkan } \\
\hline 1. & Baju & $\begin{array}{l}\text { Kemeja dewasa, kemeja } \\
\text { anak-anak, blus }\end{array}$ \\
\hline 2. & Celana & Panjang, pendek \\
\hline 3. & Rok & $\begin{array}{l}\text { Pola dasar, kerut, lingkaran, } \\
\text { lipit hadap1, lipit pipih, lipit } \\
\text { singkup, pias 8, pias 12, } \\
\text { setengah lingkaran, span }\end{array}$ \\
\hline 4. & Kulot & $\begin{array}{l}\text { Standar, setengah lingkaran } \\
\text { Tegak, kemeja, sport, } \\
\text { 5. }\end{array}$ \\
Kerah & $\begin{array}{l}\text { shiller, kemeja brood, } \\
\text { shanghay }\end{array}$ \\
\hline 6. & Lengan & $\begin{array}{l}\text { Licin, gladde, balon, } \\
\text { puncak }\end{array}$ \\
\hline
\end{tabular}

\subsection{Analisis}

Dari hasil pengujian secara kualitatif menggunakan kuesioner terhadap 30 responden, diperoleh prosentase Sangat Mirip $59 \%$, Mirip 28\%, Kurang Mirip 11\%, dan Tidak Mirip 2\%. Dari hasil tersebut dapat dikatakan bahwa hasil desain pola busana dari sistem ini cukup baik karena secara mayoritas hasilnya dinilai sangat mirip dengan data benarnya.

Dalam pembuatan pola busana secara komputerisasi ini, masih terdapat sedikit kelemahan yakni terdapat beberapa garis yang terlihat kurang halus. Hal ini terjadi terutama pada garis lurus dengan gradien sangat besar (mendekati tak hingga) atau garis dengan gradien yang sangat kecil (mendekati nol). Penyebabnya adalah penggunaan sistem piksel dalam layar komputer. Garis dengan gradien sangat besar merupakan garis lurus yang mendekati arah tegak (vertikal), sehingga dalam pembuatannya dilakukan dengan membuat garis tegak sampai beberapa piksel kemudian bergeser ke kanan atau kiri kemudian membuat garis tegak lagi sehingga terlihat bentuk yang kurang halus. Adapun ilustrasi dari proses penggambaran garis lurus pada sistem piksel ditunjukkan pada Gambar 8 . Dari gambar tersebut terlihat bahwa garis pada (a), (c), dan (d) terlihat lebih halus dibandingkan dengan garis (b) atau (e).

Sistem ini dapat membuat beberapa jenis pola busana seperti pada Tabel 4. Pola-pola ini dapat disimpan dalam bentuk file gambar. Dari gambar.tersebut dapat dicetak dan digunakan untuk proses pembuatan busana. Dengan demikian telah dihasilkan sebuah sistem yang dapat digunakan untuk membuat pola busana secara otomatis, sehingga dalam pembuatan pola dapat dilakukan dengan cepat tanpa membutuhkan biaya mahal. Meskipun demikian, masih diperlukan adanya penambahan data mengenai variasi detail busana.

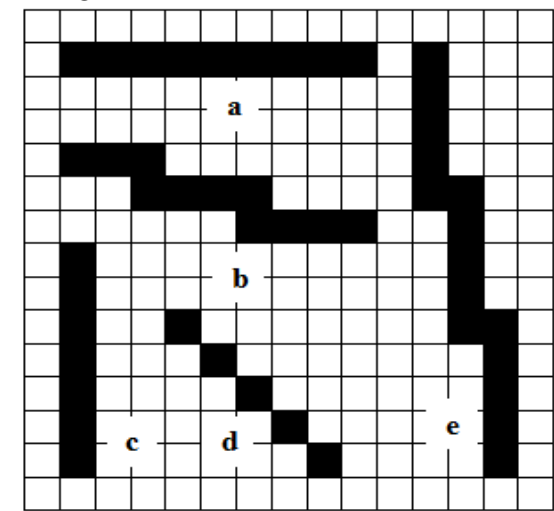

Gambar 8. Proses penggambaran garis dengan gradien (a) $\mathrm{m}=0$, (b) $\mathrm{m}$ mendekati 0 , (c) $\mathrm{m}=$ infinitif, (d) $\mathrm{m}=-\mathbf{- 1}$, (e) $\mathrm{m}$ mendekati infinitif

\section{KESIMPULAN}

Telah dihasilkan sebuah sistem yang dapat digunakan untuk membuat pola busana secara otomatis menggunakan unsur garis dan kurva bspline. Secara kualitatif menggunakan kuesioner, sistem ini mempunyai prosentase kemiripan dengan data benar sebesar 59\% Sangat Mirip, 28\% Mirip, 11\% Kurang Mirip, dan 2\% Tidak Mirip. Sistem ini dapat membuat pola busana sesuai dengan keinginan pemakai hanya dengan memilih jenis busana, detail variasi serta ukurannya. Dengan aplikasi ini, pembuatan pola busana menjadi lebih cepat dan mudah tanpa membutuhkan keahlian khusus dalam pembuatan pola. 
SYSTEMIC

Vol. 1, No. 1, Agustus 2015, 5-13

\section{REFERENSI}

[1] Lu, J.-M., Wang, M.-J. J., Chen, C.-W., \& Wu, J.-H. (2010). The development of an intelligent system for customized clothing making. Expert Systems with Applications , 799-803.

[2] Ernawati, Izwerni, \& Nelmira, W. (2008, Agustus 17). Tata busana Untuk SMK. Jakarta, Jakarta, Indonesia.

[3] Sari, P. S. (2010). Teknik Mendesain Baju Sendiri. Bekasi: Laskar Aksara.

[4] Soekarno. (2012). Buku Penuntun Membuat Pola Busana Tingkat Dasar. Jakarta: PT. Gramedia Pustaka Utama.

[5] Tan, R. T. (2011). B-SPLINE CURVES.

[6] Howard, T. (2010, January 13). An Introduction to Graphics Programming with OpenGL. Manchester, United Kingdom: University of Manchester.

[7] Anton, H., \& Rorres, C. (2005). Elementary Linear Algebra. 